\title{
ANALISIS BREAK EVEN POINT USAHA PETERNAKAN AYAM RAS PETELUR "UD. TETEY PERMAI" DI KECAMATAN DIMEMBE
}

\author{
Beiyana Winowoda; A. H. S. Salendu* M. A. V. Manese, S. J. K Umboh
}

Fakultas Peternakan Universitas Sam Ratulangi Manado, 95115

\begin{abstract}
ABSTRAK
Tujuan penelitian ini yaitu untuk menganalisis keuntungan dan break even point usaha peternakan ayam ras petelur "UD. Tetey Permai.". Penelitian ini dilaksanakan pada usaha peternakan ayam ras petelur "UD. Tetey Permai" di Kecamatan Dimembe pada bulan Juli 2018 sampai dengan bulan Agustus 2018. Data yang diambil adalah data primer dan data sekunder, data primer yaitu data yang diperoleh langsung dari pemilik perusahaan, pengelolah perusahaan, pekerja kandang dan pekerja gudang pakan. Data sekunder adalah data yang diperoleh melalui instansi terkait yang menunjang penelitian. Hasil penelitian menunjukkan bahwa usaha peternakan ayam ras petelur "UD. Tetey Permai" memperoleh keuntungan sebesar Rp3.117.715.583/periode dan sudah beroperasi diatas Break Even Point pada penjualan telur 1.129 .389 butir atau pada penjualan Rp1.694.083.907.
\end{abstract}

Kata Kunci; Keuntungan, Break Even Point

*Korespondensi(corresponding author): Email: artisesalendu@yahoo.com
ABSTRACT

ANALYSIS BREAK EVEN POINT OF LAYING CHICKEN LIVESTOCK BUSSINESS "UD TETEY PERMAI" IN KECAMATAN DIMEMBE. The purpose of this study was to analyze the Break even point of laying chicken breeding business "UD Tetey Permai." This research was conducted at the laying chicken breeding business "UD. Tetey Permai" in Dimembe District in July 2018 to August 2018. The data taken are primary data and secondary data. Primer data was obtained directly from company owners, company managers, cage workers and feed warehouse workers. Secondary data was obtained through government agencies related to research. The results showed that the laying chicken breeding business "UD. Tetey Permai" in one production period had a profit of Rp3.117.715.583 and had operated above Break Even Point on 1.129.389 eggs sales or on sales of Rp1.694.083.907.

Keywords : profit, Break Even Point. 


\section{PENDAHULUAN}

Peternakan merupakan
subsektor yang sangat penting
peranannya dalam menjaga ketahanan
pangan, karena pangan asal hewan merupakan sumber protein hewani sebagai kebutuhan pokok dalam memenuhi gizi masyarakat. Sejalan dengan meningkatnya jumlah penduduk, perubahan gaya hidup, kesadaran gizi, dan perbaikan tingkat pendidikan permintaan produk peternakan (telur, daging dan susu) terus meningkat. Menurut Umboh et al. (2014) menunjukan kontribusi sub sektor peternakan terhadap pembangunan pertanian, dimana industri perunggasan merupakan pendorong utama perkembangan usaha disub sektor peternakan Masyarakat memerlukan protein hewani dari peternakan salah satu protein hewani yang sangat diperlukan masyarakat yaitu telur yang diproduksi ayam ras petelur dengan jumlah yang sangat besar untuk mensuplay kebutuhan masyarakat.

Memon et al. (2015) produksi utama dari peternakan ayam petelur adalah telur, sedangkan daging adalah produksi sampingannya berupa ayam afkir. Hendri et al. (2012) dalam penelitiannya menunjukkan bahwa telur mempunyai kandungan gizi yang cukup banyak dan telur merupakan sumber protein hewani yang dapat dikonsumsi masyarakat.

Usaha peternakan ayam ras petelur "UD. Tetey Permai" merupakan perusahaan peternakan ayam ras petelur yang berada di Desa Tetey Kecamatan Dimembe Kabupaten Minahasa Utara yang memulai usahanya pada tahun 1995 sampai sekarang. Keberadaannya sampai saat ini mengindikasikan bahwa kegiatan usaha peternakan ayam ras petelur "UD. Tetey Permai" menguntungkan dan berkelanjutan.

Kondisi ini menjadi peluang yang dapat dimanfaatkan perusahaan untuk meningkatkan produktifitas dan produksi mengingat adanya peluang pasar yang menjanjikan. "UD. Tetey Permai" masih terbatas memasarkan produk telur ke pedagang - pedagang di daerah sekitar dan Kota Manado dan belum mampu memenuhi permintaan di luar wilayah Sulawesi Utara karena 
jumlah telur yang dihasilkan oleh perusahaan per hari masih terbatas.

Data Kabupaten Minahasa Utara dalam Angka Tahun 2018 menunjukan bahwa produksi telur ayam ras di Kabupaten Minahasa terus mengalami peningkatan. Peningkatan produksi ini diikuti pula oleh meningkatnya jumlah permintaan. Rata-rata produksi telur ayam ras di Kabupaten Minahasa Utara selama tahun 2013-2017 sebesar 1572.66 ton sedangkan rata-rata permintaan dalam kurun waktu tersebut mencapai 1700.6 ton.

Keadaan tersebut erat hubungannya dengan alokasi biaya, keuntungan sampai saat ini belum dilakukan analisis break even point sehingga keputusan hanya tergantung pemilik perusahaan.

\section{METODE PENELITIAN}

Penelitian ini dilaksanakan pada usaha peternakan ayam ras petelur "UD. Tetey Permai" di Desa Tetey Kecamatan Dimembe pelaksanaan penelitian dimulai pada bulan Juli 2018 sampai dengan Agustus 2018.

Metode pengambilan data dengan melakukan pengamatan secara langsung, wawancara dengan pemilik perusahaan, dan melihat pembukuan dari perusahaan. Data yang diambil adalah data primer dan data sekunder, data primer yaitu data yang diperoleh langsung dari pemilik perusahaan, pengelolah perusahaan, pekerja kandang dan pekerja gudang pakan. Data sekunder adalah data yang diperoleh melalui buku, jurnal, dan instansi yang terkait yang menunjang penelitian. Data dianalisis dengan menggunakan pendekatan matematik analisis keuntungan dan break even point

Soekartawi (2003) keuntungan dapat ditulis:

$$
\pi=\mathrm{TR}-\mathrm{TC}
$$

Dimana :

$\pi \quad=$ Keuntungan $(\mathrm{Rp})$

$\mathrm{TR}=$ Total Penerimaan $(\mathrm{Rp})$

$\mathrm{TC}=$ Total Biaya (Rp)

Riyanto (2001) analis break even point dapat ditulis:

$$
\begin{aligned}
& \operatorname{BEP}(\mathrm{Q})=\frac{\text { Total Biaya Tetap }}{\text { Harga jual }-\frac{\text { Biaya Tidak Tetap }}{\text { Jumlah Produksi }}} \\
& \operatorname{BEP}(\mathrm{Rp})=\frac{\text { Total Biaya Tetap }}{1-\frac{\text { Biaya Tidak Tetap }}{\text { Jumlah Penjualan }}}
\end{aligned}
$$




\section{HASIL DAN PEMBAHASAN}

\section{Karakteristik Lokasi Penelitian}

Usaha peternakan ayam ras petelur "UD.Tetey Permai" berlokasi di Desa Tetey Kecamatan Dimembe Kabupaten Minahasa Utara. Usaha ini dijalankan pada tahun 1995 dan sampai sekarang. Pemilik usaha peternakan ayam ras petelur "UD. Tetey Permai” yaitu, Bapak Frangky Palit yang berumur 42 tahun dengan pendidikan terakhir SMA. Usaha peternakan ayam ras petelur "UD. Tetey Permai" dijalankan atas niat ingin mengelola usaha sendiri dikarenakan memiliki lahan yang sangat luas. Untuk mengurangi biaya produksi pemilik juga sudah memiliki mesin pencampur pakan, mesin penggiling jagung, timbangan pakan untuk menghemat biaya, misalnya pakan ayam ras petelur yang digiling sendiri sehingga yang dibutuhkan hanya bahan baku.

Menurut Malik (2003) ayam dewasa kelamin pada umur 19 minggu dan ditandai dengan telur pertama. Rasyaf (2005) produksi telur ayam ras petelur berkisar 260-280 butir per tahun Berdasarkan hasil penelitian ayam ras petelur "UD. Tetey Permai" mulai berproduksi 19 minggu dengan produksi 6,860 butir per hari produksi puncak pada umur 28 minggu diatas 77 minggu produksi mulai menurun sehingga diafkirkan apabila diberikan pakan terus menerus akan mengakibatkan biaya pakan meningkat.

Biaya Produksi Usaha Peternakan Ayam Ras Petelur "UD. Tetey Permai".

Usaha peternakan ayam ras petelur "UD. Tetey Permai” biaya produksi adalah sejumlah uang dikeluarkan oleh perusahaan dari mulai pembuatan bangunan kandang, gudang dan fasilitas penunjang sampai pada masuknya bibit (DOC), pakan, tenaga kerja, obat-obatan, vaksin sampai ayam sudah tidak berproduksi atau afker selama satu periode produksi.

\section{Biaya Tetap (Fixed Cost)}

Biaya tetap yang dikeluarkan selama satu periode produksi usaha peternakan ayam ras petelur "UD. Tetey Permai” sebesar Rp722.194.500. Biaya tetap dapat dilihat pada Tabel 1. 
Tabel 1. Biaya Tetap Usaha Peternakan Ayam Ras Petelur "UD. Tetey Permai" No Uraian Rp/Periode Penyusutan/Tahun

\begin{tabular}{llrr}
\hline 1. & Kandang & 165.000 .000 & 16.500 .000 \\
2. & Peralatan Kandang & 234.272 .500 & 17.634 .167 \\
3. & Gudang & 151.000 .000 & 13.400 .000 \\
4. & Peralatan Gudang Pakan & 41.742 .000 & 3.780 .667 \\
5. & Peralatan Gudang Telur & 8.200 .000 & 2.506 .667 \\
6. & Peralatan air & 7.980 .000 & 1.742 .917 \\
7. & Kendaraan & 114.000 .000 & 11.400 .000 \\
\hline & Total & 722.194 .500 & 66.964 .417 \\
\hline
\end{tabular}

Biaya Tidak Tetap (Variabel Cost)

Biaya tidak tetap (variabel

cost) pada usaha peternakan ayam ras petelur "UD. Tetey Permai" biaya tidak tetap yang dikeluakan selama satu periode produksi sebesar Rp3.187.800.000 biaya per tahun sebesar Rp1.593.900.000 dapat dilihat pada

Tabel

Tabel 2. Biaya Tidak Tetap Usaha Peternakan Ayam Ras Petelur "UD. Tetey Permai"

\begin{tabular}{|c|c|c|c|}
\hline No & Uraian & Rp/Periode & Rp/Tahun \\
\hline 1. & Bibit & 98.500 .000 & 49.250 .000 \\
\hline \multirow[t]{5}{*}{2.} & Pakan Ternak (Kg/hari) & & \\
\hline & - Starter & 157.300 .000 & 78.650 .000 \\
\hline & - Grower & 357.000 .000 & 178.500 .000 \\
\hline & - Layer & 2.079 .000 .000 & 1.039 .500 .000 \\
\hline & Jumlah & 2.593 .300 .000 & 1.296 .650 .000 \\
\hline 3. & Obat-obatan dan Vaksin & 30.000 .000 & 15.000 .000 \\
\hline \multirow[t]{5}{*}{4.} & Tenaga Kerja & & \\
\hline & a. Mandor Lapangan & 60.000 .000 & 30.000 .000 \\
\hline & b. TK Kandang & 294.000 .000 & 147.000 .000 \\
\hline & c. TK Gudang Pakan & 81.600 .000 & 40.800 .000 \\
\hline & Jumlah & 435.600 .000 & 217.800 .000 \\
\hline \multirow[t]{6}{*}{5.} & Lainnya & & \\
\hline & $\mathrm{BBM}$ & 10000.000 & 5.000 .000 \\
\hline & Listrik & 20.400 .000 & 10.200 .000 \\
\hline & Baki Telur & 7.000 .000 & 3.500 .000 \\
\hline & Jumlah & 30.400 .000 & 15.200 .000 \\
\hline & Total & 3.187 .800 .000 & 1.593 .900 .000 \\
\hline
\end{tabular}


Tabel 3. Total Biaya Produksi Usaha Peternakan Ayam ras Petelur "UD. Tetey Permai"

\begin{tabular}{|c|c|c|c|}
\hline No & Uraian & Rp/Periode & Rp/Tahun \\
\hline \multicolumn{4}{|c|}{ Biaya Tidak Tetap } \\
\hline 1 & Bibit & 98.500 .000 & 49.250 .000 \\
\hline 2 & Pakan Ternak (Kg/hari) & 2.593.300.000 & 1.296 .650 .000 \\
\hline 3 & Obat-obatan dan Vaksin & 30.000 .000 & 15.000 .000 \\
\hline 4 & Tenaga Kerja & 435.600 .000 & 217.800 .000 \\
\hline \multirow[t]{2}{*}{5} & Lainnya $^{\wedge}$ & 30.400 .000 & 15.200 .000 \\
\hline & Sub Jumlah & 3.187 .800 .000 & 1.593 .900 .000 \\
\hline II & \multicolumn{3}{|l|}{ Biaya Tetap /Penyusutan } \\
\hline 1 & Kandang & 165.000 .000 & 16.500 .000 \\
\hline 2 & Peralatan Kandang & 234.272 .500 & 17.634.167 \\
\hline 3 & Gudang & 151.000 .000 & 13.400 .000 \\
\hline 4 & Peralatan Gudang Pakan & 41.742 .000 & 3.780 .667 \\
\hline 5 & Peralatan Gudang Telur & 8.200 .000 & 2.506 .667 \\
\hline 6 & Peralatan Air & 7.980 .000 & 1.742 .917 \\
\hline \multirow[t]{3}{*}{7} & Kendaraan & 114.000 .000 & 11.400 .000 \\
\hline & Sub Jumlah & 722.194 .500 & 66.964 .417 \\
\hline & Jumlah & 3.909.994.500 & 1.660 .864 .417 \\
\hline
\end{tabular}

Berdasarkan Tabel 3 bahwa total biaya yang dikeluarkan usaha peternakan ayam ras petelur "UD. Tetey permai" selama satu periode produksi sebesar Rp3.909.994.500, biaya per tahun sebesar
Rp1.660.864.417.

Tabel 4. Presentase Komponen Biaya Terhadap Total Biaya "UD. Tetey Permai"

\begin{tabular}{rlrr}
\hline & & Rp/Periode & $\begin{array}{r}\text { Presentase } \\
\text { No. }\end{array}$ \\
\hline 1 Uraian & Bibit & 49.250 .000 & 2.97 \\
2 & Pakan Ternak (Kg/hari) & 1.296 .650 .000 & 78.07 \\
3 & Obat-obatan dan Vaksin & 15.000 .000 & 0.90 \\
4 & Tenaga Kerja & 217.800 .000 & 13.11 \\
5 & Lainnya ${ }^{\wedge}$ & 15.200 .000 & 0.92 \\
6 & Penyusutan & 66.964 .417 & 4.03 \\
\hline & Jumlah & 1.660 .864 .417 & 100 \\
\hline
\end{tabular}


Berdasarkan Tabel 4 bahwa komponen biaya terbesar yaitu biaya pakan dan tenaga kerja yaitu sebesar Rp1.296.650.000 atau 78,07 persen. Peningkatan biaya tidak tetap ini disebabkan karena meningkatnya harga pakan dan konsumsi pakan.biaya tenaga kerja sebesar Rp217.800.000 atau 13,11 persen dari total biaya produksi dan biaya terkecil yaitu biaya obat-obatan dan vaksin sebesar Rp15.000.000 atau 0,90 persen dari total biaya. Total biaya yang dikeluarkan "UD. Tetey Permai" sebesar Rp1.660.864.417.

Penerimaan Usaha Peternakan Ayam Ras Petelur "UD. Tetey Permai"

Menurut Triana et al, (2007) penerimaan dari usaha ayam ras petelur diperoleh dari produksi telur utuh, telur retak, dan ayam afkir. Penerimaan pada usaha peternakan ayam ras petelur "UD. Tetey Permai" yaitu berupa penjualan telur utuh, telur afker, ayam afker dan pupuk kompos "UD. Tetey Permai” selama satu periode produksi sebesar Rp6.372.480.000.
Penerimaan telur utuh diperoleh dari hasil rata-rata hen-day production (HDP) 70 persen. Berdasarkan hasil penelitian menunjukan bahwa produksi telur per periode sebanyak 3.704.400 butir dikalikan dengan harga

Penerimaan telur afker rata-rata 1,5 persen dari data maka diperoleh penerimaan telur afker selama satu periode produksi sebanyak 79.380 butir dikalikan dengan harga Rp1.000.

Penerimaan ayam afker diperoleh dari jumlah ayam dikalikan dengan harga per ekor Rp60.000 Penerimaan penjualan ayam afker sebesar Rp588.000.000. Menurut Mongi (2014) penjualan ayam afkir dilakukan karena ayam tersebut tidak berproduksi lagi.

Penerimaan pupuk kompos diperoleh dari kotoran ayam dikalikan per kilogram Rp250. Total penerimaan usaha peternakan ayam ras petelur "UD. Tetey Permai" sebesar Rp6.372.480.000 dapat dilihat pada Tabel 5. 
Tabel 5. Penerimaan Usaha Peternakan Ayam Ras Petelur "UD. Tetey Permai"

\begin{tabular}{rlrr}
\hline No. & Penerimaan & Volume & $\begin{array}{r}\text { Penerimaan } \\
(\text { Rp })\end{array}$ \\
\hline 1. & Telur Utuh (Butir) & 3.704 .400 & 5.556 .600 .000 \\
2. & Telur Afker (Butir) & 79.380 & 79.380 .000 \\
3. & Ayam Afker (Ekor) & 9.800 & 588.000 .000 \\
4. & Pupuk Kompos (Kg) & 599.400 & $148,500,000$ \\
\hline & Total Penerimaan & & 6.372 .480 .000 \\
\hline
\end{tabular}

Keuntungan Usaha Peternakan Ayam Ras Petelur "UD Tetey Permai"

Asnawi (2009) keuntungan pada usaha peternakan ayam petelur merupakan selisih antara penerimaan total dengan biaya total produksi yang dikeluarkan. Berdasarkan hasil penelitian pada Tabel 6 bahwa keuntungan yang diperoleh usaha peternakan "UD. Tetey Permai" sebesar Rp3.117.715.583 per periode.
Rembet et al. (2014) melaporkan hasil penelitiannya bahwa keuntungan yang diperoleh usaha ternak ayam ras petelur sebesar Rp2.307.361.460. Bila dilihat dari harga pokok produksi (HPP) total biaya dibagi dengan jumlah penerimaan telur HPP sebesar Rp860 apabila dibandingkan dengan tingkat harga jual Rp1.500 maka keuntungan per butir yang diperoleh usaha "UD. Tetey Permai"sebesar Rp640.

Tabel 6. Keuntungan Usaha Peternakan Ayam Ras Petelur "UD. Tetey Permai"

\begin{tabular}{llrr}
\hline No & Uraian & Rp/Periode & Rp/Tahun \\
\hline I & Penerimaan & 6.372 .480 .000 & 3.186 .240 .000 \\
II & Biaya & & \\
1 & Biaya Tidak Tetap & 3.187 .800 .000 & 1.593 .900 .000 \\
2 & Biaya Tetap & 66.964 .417 & 33.482 .209 \\
& Jumlah & 3.254 .764 .417 & 1.627 .382 .209 \\
\hline III & Keuntungan (I-II) & 3.117 .715 .583 & 1.558 .857 .792 \\
\hline
\end{tabular}


Analisis Break Even Poin (BEP) Usaha Peternakan "UD. Tetey Permai"

Analisis break even point usaha peternakan ayam ras petelur "UD. Tetey Permai" menggambarkan break even point pada volume produksi, kuantitas dan volume penjualan selama satu periode produksi. Pada Tabel 7 diketahui bahwa usaha peternakan ayam ras petelur "UD. Tetey Permai" produksi telur selama satu periode sebesar 3.704 .400 butir break even point pada 1.129.389 butir, sedangkan untuk jumlah penjualan selama satu periode sebesar Rp5.556.600.000 break even point pada posisi penjualan Rp1.694.083.907 artinya usaha peternakan ayam ras petelur "UD. Tetey Permai" pada kondisi awal sudah break even point selanjutnya usaha tersebut mengalami keuntungan.

Tabel 7. Analisis Break Even Point Usaha Peternakan Ayam Ras Petelur "UD. Tetey Permai" Selama Satu Periode Produksi.

\begin{tabular}{rlr}
\hline No & Uraian & Nilai \\
\hline I & BEP Unit & \\
1 & Total Biaya Tetap (Rp) & 722.194 .500 \\
2 & Harga Jual (Rp) & 1.500 \\
3 & Biaya Tidak Tetap (Rp) & 3.187 .800 .000 \\
& BEP Unit (Butir) & 1.129 .389 \\
\hline II & BEP Sales & 722.194 .500 \\
\hline 1 & Total Biaya Tetap (Rp) & 3.187 .800 .000 \\
2 & Biaya Tidak Tetap (Rp) & 3.704 .400 \\
3 & Jumlah Penjualan (Butir) & 1.694 .083 .907 \\
\hline & BEP Sales (Rp) & \\
\hline
\end{tabular}




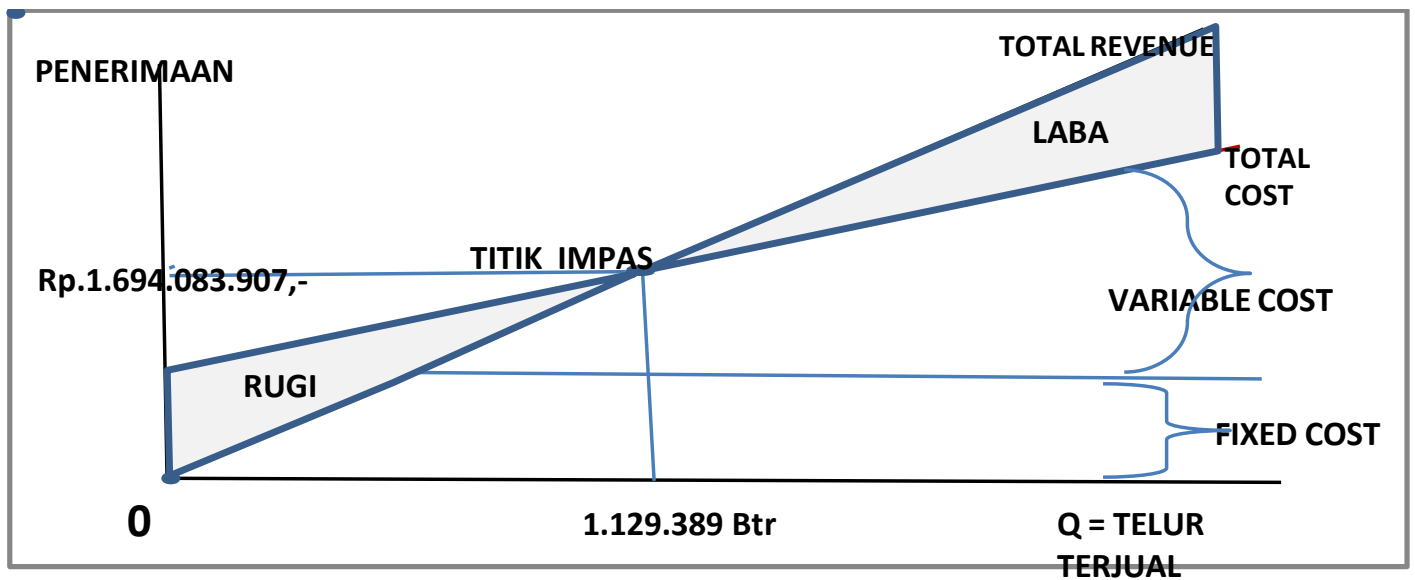

\section{Gambar 1 . Break Even Point Usaha Peternakan Ayam Petelur "UD. Tetey Permai" Selama Satu Periode Produksi.}

Keterangan :

1. Sumbu datar (sumbu $\mathrm{x})$ menyatakan volume penjualan yang dapat dinyatakan dalam satuan kuantitas atau rupiah pendapatan pejualan.

2. Sumbu tegak (sumbu y) menyatakan pendapatan penjualan telur dan biaya dalam rupiah.

3. Impas adalah terletak pada perpotongan garis pendapatan penjualan telur dengan biaya.

Bila dilihat dari titik perpotongan tersebut ditarik garis tegak ke sumbu $\mathrm{x}$, akan diketahui pencapaian impas berdasarkan volume penjualan telur. Jika dari titik impas ditarik tegak lurus ke sumbu y, akan diketahui pencapaian titik impas berdasarkan pendapatan penjualan telur.

4. Daerah sebelah kiri titik impas, yaitu bidang diantara garis total biaya dengan garis pendapatan penjualan merupakan daerah rugi, karena pendapatan penjualan lebih rendah dari total biaya. Sedangkan daerah di sebelah kanan titik impas, yaitu bidang diantara garis pendapatan penjualan dengan garis total biaya merupakan daerah laba, karena pendapatan penjualan lebih tinggi dari total biaya.

\section{KESIMPULAN}

Usaha peternakan ayam ras petelur "UD. Tetey Perma" 
memperoleh keuntungan sebesar $\mathrm{Rp}$ Rp3.117.715.583/Periode sudah beroprasi diatas break event point pada penjualan telur sebesar 1.129.389 butir atau Rp1.694.083.907.

\section{DAFTAR PUSTAKA}

Alamsyar A., A. Muis dan Sulaeman. 2015. Analisis titik pulang pokok usaha peternakan ayam ras petelur CV. Menara di kota Palu. Program Studi Agribisnis Fakultas Pertanian Universitas Tadulako Palu. Jurnal Agroland 22 (2) : $154-162$.

Asnawi A. 2009. Perbedaan tingkat keuntungan usaha peternakan ayam ras petelur antara sebelum dan sesudah memperoleh kredit PT BRI di Kabupaten Pinrang Buletin Ilmu Peternakan dan Perikanan. 1 (1) :10-17

Hendri R., G. Ikhsan. dan J. Irma. 2012. Analisis kelayakan usaha ayam ras petelur (gallus $\mathrm{sp}$ ) studi kasus pada usaha ternak subur jln.Teropong KM 2.5 Jaya Kabupaten Kapar.Jurnal Penelitian Sungkai (1):34-39. Fakultas Pertanian Universitas Pasir Pengaraian.

Juniady, S. S. 2001. Kajian terhadap beberapa metode penyusutan dan pengaruhnya terhadap perhitungan beban pokok penjualan (cost of good sold).
Jurnal Akuntansi dan Keuangan 3 (2) : 157-173.

Nawawi M A., A.S. Andayani dan Dinar. 2017. Analisis usaha peternakan ayam petelur (studi kasus pada peternakan ayam petelur Cihaur, Maja, Majalengka, Jawa Barat) business analysis of layer farm (case study layer farm Cihaur, Maja Lengka, West Java) Agrivet Journal (5): 1-6

Malik, A. 2003. Dasar Ternak Unggas. Fakultas Peternakan Perikanan. Universitas Muhammadiyah Malang, Malang.

Memon, I. N, S., M. Naonasi, S. Asif, T. Shah and M. B. Peerzado. 2015. Economic analysis of poultry egg production in Quetta District Balochistan. Journal Fisheries Livest Production, 3(1):3-7.

Mongi, H. 2014. Analisis profitabilitas usaha peternakan ayam petelur bina ternak mandiri di Kelurahan Mapane Kecamatan Poso Pesisir. Fakultas Peternakan Universitas Sintuwu Maroso. Fakultas Peternakan Universitas Sintuwu Maroso. Jurnal Agropet 11 (1) : 80-92.

Rasyaf, 2005. Beternak Ayam Petelur. Penebar Swadaya. Jakarta.

Rembet, A, A., F.S. Oley, A. Makalew dan E.K.M. Endoh. 2013. Analisis titik impas usaha ternak ayam ras petelur "dharma gunawan" di 
Kelurahan Paniki Bawah Mapanget Kota Manado (Studi Kasus). Jurnal Zootek 33 (1): 11-20.

Riyanto B. 2001. Dasar-dasar Pembelanjaan Perusahaan Ed 1V Cet V11. Penerbit BPFE, Yogyakarta.

Soekartawi, 2003.Agribisnis Teori dan Aplikasinya. Analisis Usaha Tani. PT. Raja Grafindo Persada, Jakarta.

Triana A, T. Salam , M. Muis. 2007. Analisis pendapatan usaha peternakan ayam ras petelur periode layer di Kecamatan Maros. Jurnal Agrisistem. 3 (1); 11-25.

Umboh, S.J.K., D.B. Hakim, B.M. Sinaga dan I.K Kariyasa. 2014. Impact of domestic maize price changes on the performance of small scale broiler farming in Indonesia.Media Peternakan. 37 (3): 198-205. 